Article

\title{
Modernist Women Writers and Whimsy: Marianne Moore and Dorothy Parker
}

\author{
Will May \\ Department of English, University of Southampton, Southampton S017 1BJ, UK; w.may@soton.ac.uk
}

Received: 1 October 2019; Accepted: 17 February 2020; Published: 6 March 2020

\begin{abstract}
This article assesses the work of Dorothy Parker (1893-1967) and Marianne Moore (1887-1972) in relation to the aesthetic category of whimsy. It considers how whimsy has been used as a term of dismissal for American women poets, outlines ways both writers' receptions have been informed by this context, and explores questions of cost, worth, and value raised by their work. It situates whimsy in relation to Sianne Ngai's account of diminutive modes in Our Aesthetic Categories (2015) and suggests why American women's modernist poetry can be a useful context for exploring the aesthetic and cultural associations of whimsy.
\end{abstract}

Keywords: Moore; Parker; whimsy; poetry; poetics; New York; modernism

Paper: Dorothy Parker's publishing career begins with two women positing whimsy as a literary category:

"I'm reading that new thing of Locke's

So whimsical isn't he? Yes-"

"My dear, have you seen those new smocks?

They're nightgowns-no more, and no less." (Parker 2010, p. 203)

This is a passing mention, forgotten by the two speakers as quickly as the 1914 novel, which prompted it, the bestselling Fortunate Youth by British writer William John Locke. The poem, 'Any Porch', continues with sixteen couplets which yawn their way through an apparently indifferent conversation. Parker thought the poem sufficiently thin to omit from her Collected Poems, although its publication in Vanity Fair secured her first job as staff writer for Vogue (Meade 1988, p. 34). While the poem is a gentle satire on gossip, it blurs the lines between mimicry and echo: Parker's biographer glosses her early poems as 'trivia' (Meade 1988, p. 31), as if the poem were as insubstantial as the smocks. Yet it is striking that Parker's first published poem records a response to a male contemporary by a female reader that is half-engaged, half-dismissive in its gloss of 'whimsical'. It is telling, too, that Parker was keen to remove the poem from her corpus. The women's bored belittling of Locke might tell us they value literature no more than lingerie. However, the humour of the quatrain comes not only from the women's exacting ethical standards ('they're nightgowns') but the combination of precision and euphemism that expresses them ('no more, and no less'). When two people have agreed that a writer's work is characterised by the whimsical, what, exactly, have they agreed on?

Miriam-Webster defines whimsy as 'a fanciful or fantastic device, objective, or creation, especially in writing or art' (Whimsy 2019). Yet if the dictionary suggests a mode or quality particular to imaginative literature, it is hardly well documented. The Princeton Encyclopedia of Poetry and Poetic Terms contains no entries for the term. Neither monograph index nor journal article bears its mark. Literary critics take us little further than the two women on the porch, having such disdain for the category that even the act of definition would be an engagement too far. Susan Sontag upbraids the 'cold' and 'self-referring' whimsy of Ionesco where 'the terrible is always, somehow circumscribed by the cute' (Sontag 1966, p. 111), but says no more on the topic, in contrast to her infamous inventory of 
camp. More recently, Geoff Dyer has suggested 'nothing makes any difference with whimsy, whimsy is for lower stakes [ ... ] there are no risks in whimsy. People think of whimsy as doing whatever you feel like, but there's less to whimsy than that' (Dyer 2012, p. 45). In as far as it is part of any critical conversation, it continues to be the word put at the farthest reach from anything worthy of our sustained attention. Dyer's own circulation around the word bears out his diagnosis. However unimportant we might think the category, it beguiles us by being even less significant than it appears. In all these accounts, disavowal sounds out more clearly than definition. Yet if it is always for low stakes, why is it such a crime, and why do poems and poets keep committing it?

As a term, whimsy has many of the 'diminutive' qualities Sianne Ngai explores in Our Aesthetic Categories: Zany, Cute Interesting (Ngai 2012, p. 59). Like her definition of 'cute', it is a word which sounds a strong note of judgement: it encourages us to believe we are in charge of it. It beckons us in, but we are minded to develop a distaste for it. In the women's conversation on the porch, it is less important for them to understand what formal attributes Locke's 'whimsical' work might have than to acknowledge a shared dismissal. It is significant that their use of the term aligns the work with its author: behind every whimsical work is a whimsical writer. The dismissal is studiedly low-key rather than challenging: the whimsical draws attention to itself, but in ways that do not threaten the mainstream. To discern whimsy, as Ngai suggests of minor literary categories, we will need to identify the 'low, often hard-to-register flicker of affect accompanying our recognition of minor differences from a norm' (Ngai 2012, p. 18). The hard-to-register is also hard to disentangle. The whimsical sounds affiliation with other, more aesthetically familiar terms - the camp, the comic, the eccentric, the playful. Yet unlike many of these terms, it has sometimes been an expedient category for critics to use of readers. The word appears, briefly but pointedly, in I.A. Richards' Practical Criticism, as he attempts to drum out the 'personal-whimsy' response of untutored eyes and ears (Richards 1930, p. 255). English studies was working hard to consolidate its position as a rigorous academic subject, and anything that was not criticism was merely whimsy. This suggests a potentially dangerous quality of the term: it has the power not only to topple a work of literature but also the critical responses to it. This doubleness seems a threat for an apparently toothless and insignificant word. In this article, I want to challenge the claim that whimsy is for low stakes and that the apparently generic conversation happening in 'Any Porch' is not one we should look at more carefully. I want to simultaneously explore the socially-constructed nature of the term, frequently an insult or act of dismissal which clings particularly to women poets, while considering whether whimsy might have some inherent characteristics that attach themselves to certain kinds of poetic texts. To do this, I want to bring Parker herself into conversation with a female contemporary poet who shares surprising affinities with her: Marianne Moore.

Marianne Moore (1887-1972) and Dorothy Parker (1893-1967) spent most of their lives on two islands separated by a bridge. They were also two of the most identifiable American women writer-celebrities of the twentieth century: Moore, the baseball-watching national poet of America dressed in academic robes, Parker, the epigram-laden wit haunting the cocktail bars of New York. If Parker's satirical and urbane verses seem to have little to do with Moore's gnomic and often involuted poems, their critical receptions, as we shall see, include strategic interventions that bear striking similarities. This article will consider some of the wider historical and cultural contexts for the term whimsy, before considering how these might play out in the poetics, aesthetics, and reception dynamics of both writers. It will then go on to suggest some distinct ways both poets examine the charges and costs both of writing whimsy and being whimsical writers.

\section{Whimsy in Context}

If whimsy has a literary history beyond being an expedient dismissal, it begins with John Dennis' 1704 treatise, The Grounds of Criticism in Poetry. For Dennis, the term offered a key differentiation: 'poetry is either an Art, or Whimsie and Fanaticism' (Dennis 1704, p. 5). In this formulation, whimsy is a work that has gone wrong, and failed to become a poem. It gives us a clue as to why the word might recur so deliberately and variously in literary insults across poetic genres and periods but so 
infrequently in critical and scholarly literature. It is the creation that has not spent enough time with the creator, and should not be worth spending our time over. Two historical examples hint at the wide range of uses, or abuses, the term might encompass. For William Hazlitt, whimsy is the maniacal enthusiasm holding back Coleridge from greatness, meaning his work is 'fancy-bred from the maggots of his brain' (Hazlitt 1817, p. 488). It describes the inability of his art to be sure of where it is heading, positing whimsy as a kind of manic humor. For Samuel Johnson, the poet Edward Young is 'whimsical' for his decision to move from rhymed to unrhymed verse (Johnson 1875, p. 433). The adjective is justified for his apparently quixotic shifts in form, for choices too rapid and extreme to suggest due care. In this way, the critical term enacts its own kind of mercurial shiftiness: by never committing itself to a specific authorial sin, it is suitably vague to be endlessly appropriated.

If the term has been apparently banished from serious critical consideration, the risk of poetry being 'trivial' or light verse not being 'good enough' has been a constant in literary conversation. It was felt particularly sharply by modernist American poets: as Bonnie Costello has noted, the dominant mode of twentieth-century American poetry is 'tragi-comic', yet its reception often gives humour short shrift (Costello 2012, p. 340). Susan Howe in The Birth-mark: Unsettling the Wilderness in American Literary History notes American culture has a particular fraught relationship with the capricious and the whimsical, and polices its poetry accordingly: to be playful in a poem is also to play truant from 'canonical American literary expression'. Its democratic structure must banish 'false notion, caprice, whim' (Howe 1993, p. 12). Whimsy is the thing we leave behind, the failure which we endeavour to free ourselves from to yoke ourselves to structures and sentences more permanent. This notion might have distinct resonance for a national culture built on a constitution, rather than a series of eccentric legal precedents. Howe also notes 'fancy' is 'an irredeemably feminine word for most Americans', summoning the long Anglo-American tradition of aligning caprice with women poets. As I have noted elsewhere (May 2019, p. 74), notions of triviality and the whimsical have often been used to undermine and contain the role of intellectual women in society, as in Mary Wollstonecraft's observation her educated female contemporaries were said to be 'teeming with capricious fancies' (Wollstonecraft 2008, p. 103), or Margaret Cavendish's conviction that female wit needs the 'discretion' of male prudence in The Female Academy (Cavendish 1668, p. 654). Whimsy's status as a negative counter-definition shapes its long association with women poets: Adrienne Rich's 1977 'Women and Honor' notes that women, and by association their writing, have often been characterised as 'generically whimsical, deceitful, subtle' (Rich 1995, p. 186). Rich's collocation of the whimsical with the generic suggests the persistent link between questions of trust, genre, and form: to be whimsical is not only a way of not being taken seriously but also a way not to be trusted.

Given this literary and historical context, we may not be surprised to find the term's pejorative associations haunt the reception of a number of female American poets, as in the baffled account in Atlantic Monthly of Emily Dickinson's poetry as 'whimsical memoranda' which 'have a certain something, which, for want of a more precise name, we term quality' (Aldrich 1892, p. 133). The critical formulation is striking: 'whimsical' stands in for a term the male reader cannot find for a poetics he cannot decipher. His 'quality' is less a seal of approval than the identification of particularity, an acknowledgment of something distinct rather than something with distinction. It also suggests the double-bind of whimsy for women poets: the power of disavowal can be applied to the experimental and obscure, as with Dickinson, or that which appears generic and ephemeral. Can a vague term with such a history of projection and social construction be a useful aesthetic category or poetic mode? 'There is poetry and there is not' (Parker 1928, p. 77) wrote Parker, in a sharp 1927 review, apparently as clear on the binary distinction as John Dennis had been two hundred years earlier. How might we tell the difference?

\section{Bridging the Gap}

Both Moore and Parker were subject to whimsical dismissal at various points in their literary career and posthumous receptions: their own writing and critical accounts of it often challenge, circumvent, 
or play with these characterisations. What is the nature of these dismissals, in what ways have both writers and readers sought to address them, and what might this tell us about the category itself? In a 2004 review, William Logan identified whimsy as the 'besetting weakness' in Moore's work, her status as a public figure making 'poets, and poetry, seem slightly ridiculous' (Logan 2004). The charge linked her poetics with her persona, repeating a familiar trope of her critical reception: Cliff Mak notes how often her fastidious precision is equated with an 'ingrown cuteness' (Mak 2016, p. 873), echoing Ngai's categorisations. The poem which begins Moore's first collection is a dedication to an inter-mural rat, yet it is Moore's extra-mural activities which have given critics as much cause for concern: extolling the virtues of baseball or, in 1955, agreeing to devote serious time to naming the Ford Motor Company's newest car. Whimsy seems a challenging term precisely because its adhesive force is felt equally by the poet and the poem. Logan's attack suggests whimsy has the power to infect all poets and poetry with the 'ridiculous': it is a potent insult-by-association.

Moore criticism often characterises her poetry as a series of eccentric forms. Writing in 1982, David Bromwich compared her use of poetic innovation to 'a friend's matinal fondness for mango juice' (Bromwich 1982, p. 340); John Ashbery was keen to differentiate her Mary Poppins, presumably one administering medicine to help us stomach the sugar rather than the other way round (O'Connor 1988, p. 30). Here is, in part, an urge to out-quip a famously self-effacing and original poet, who tended to describe herself in terms still more bizarre than these: in a 1959 letter to Elizabeth Bishop, Moore cast herself halfway between 'Jack Abbot and Peter Rabbit' (Costello 1984, p. 130). The idea of the poet shifting between two competing identifies or locations is echoed in critical accounts, too. Robert Crawford notes the unsettling pull between 'whimsy and correctness' (Crawford 2004, p. 251) in her work: here, the playful and fastidious are in committed dialogue. Meanwhile, Cliff Mak has recently located within Moore's poetry an 'authoritative kind of surplus style', or a 'series of instabilities virtuosically integrated into a greater stylistic whole' (Mak 2016, p. 875). The tension between 'surplus' and 'authoritative' echoes the 'whimsical' and 'correct' in Crawford's reading, opening the door to the very aspects of Moore's work earlier critics have sought to downplay. For both Mak and Crawford, whimsy is part of a dynamic binary rather than, as for Logan, something immutable or all-pervasive. As T.S. Eliot remarks of Moore's work, 'if you aim at only the poetry in poetry, there is no poetry either' (Eliot 1935, p. 11). If poets and their readers could agree what whimsy was, would they also be able to agree how much a poem could take?

The same question haunts another famous defense of Moore, and one that feels keenly what damage a word like 'whimsy' might do. It appears in Elizabeth Bishop's memoir:

Lately I have seen several references critical of [Moore's] poetry by feminist writers, one of whom described her as 'a poet who controlled panic by presenting it as whimsy'. Whimsy is sometimes there, of course, and so is humour (a gift these critics sadly seem to lack). Surely there is an element of mortal panic and fear underlying all works of art? Even so, one wonders how much of Marianne's poetry the feminist critics have read. (Bishop 1994, pp. 143-44)

This passage has most often been marshalled to explore the underlying panic of Moore's or Bishop's work, while the other element is neutralised or ignored: Lionel Kelly suggests Bishop 'has no animus against whimsy for itself' (Kelly 2000, p. 1). Certainly, it seems to be the spirit of whimsy Bishop calls on in her poetic epistle to Moore, when she asks her to 'please come flying' with angels riding 'on the broad black brim of your hat' (Bishop 1994, p. 83). It is significant, too that whereas Bishop makes panic universal, underlying all works of art, whimsy, much more pertinent to Moore, is brushed aside with 'of course', normalizing as consensus something which, as have seen, is a vexed term with a long history of containment and dismissal. 'Of course' so often masks the things we have only recently come to know, or are trying not to highlight. Bishop resituates whimsy as a 'gift' the critic is lacking, rather than a poetic error to be corrected. Her critics are charged not only with misreading, but not reading widely enough. Over the last decade, we have sought new terms for the established languages of mastery and critique. What would our responses look like if we attended to 
the whimsical, rather than sought to deny its existence? Bishop suggests that as well as defending poets from the charge, we might explore ways to make ourselves more alert to its power.

It is helpful here to turn to Dorothy Parker, a writer apparently hostile to whimsy, but aware of its pervasive role in literary culture. If 'whimsical' is a term of dismissal in her first published poem, she returns to the word with an unusually repetitious irritation in her own reviewing. Examples from her Broadway reviews give a hint of the circular quality of these uses and suggest its heightened currency in early twentieth-century America. Her account of Roi Cooper Megrue's 1924 play Honors Are Even casts a wry glance at a heroine's 'whimsical wondering', and frequently 'whimsical' rejoinders, casting her as 'the most determinedly whimsical heroine you ever saw in your life' (Parker 2014, p. 240). Arthur Richman's comedy Not So Long Ago has a 'whimsical tenderness', later qualified as 'overmuch whimsical tenderness', before she notes 'it is surprising what a long, long way even a little whimsical tenderness will go [ ... ] give me but one or two acts of it, and I'll manage to scrape along for a whole year' (Parker 2014, p. 145). Here, she suggests the question may be one of degree rather than kind. Meanwhile, J.M. Barrie's Dear Brutus (1917), a play of middle-aged wish-fulfilment, prompts the frustrated cry that 'it is practically impossible to talk about the play without bringing in "whimsical charm", and that spoils everything [... ] the play is simply packed with whimsical charm, and what can you do about it?' (Parker 2014, p. 58). It is notable how frequently in these cases, Parker draws our attention to a male writer's representation of a female character. The whimsical is the way to police the female and the sexual, to keep it securely in the category of entertainment. The empty return of these phrases in Parker's criticism also suggests the cloying quality of whimsy, its need to draw us in, making us unable to shape our response into critical distance. Its frequent arrival in her often satirical reviews suggests an aesthetic, as well as a cultural unease, at the term. It allows us to experience nothing, and to say nothing about what we have experienced: as Parker complains, 'what can you do about it?'.

Her ire is apparent in the 'whimsical' writer who suffered most under Parker's critical eye. Her notorious A.A. Milne review for the New Yorker under her popular pseudonym of the 'Constant Reader' confesses that by the first mention of 'Hunny [ ... ] this Tonstant Weader Fwowed up' (Parker 1970, p. 101). She quotes Piglet's lyric 'The more it/SNOWS-tiddely-pom', before noting his 'frequent droppings into more cadenced whimsy'. The metaphor is somewhere between cute and scatological. Her review did serious damage: a 1956 profile in Time magazine carried Milne's complaint that 'if I write anything less realistic, less straightforward than "the cat sat on the mat", I am [called] whimsical", that "most loathsome adjective"' (Unsigned Review 1956). It was an expedient attack to guard her own reputation, too: once Parker's first poetry collection Enough Rope (1927) passed into its third edition, her publisher made plans to sell her as 'another A.A. Milne'. This prompted an unloved temporary nick-name of 'Dotty-the-Pooh' (Adams 1935, p. 706), an advertising strategy she was keen to abandon. By pinning her word on Milne, she avoids it being applied to her own work. Yet her apparently physical disgust at whimsy belies her interest in having more purchase on the term: her reviews highlight the difficulty of defining its characteristics. How might her own poetry explore what 'cadenced whimsy' could do? If its presence in a work of art is usually overdone, might it still provide us with something worth keeping? In the remainder of the essay, I will identify ways the poetry of Moore and Parker complicate and thicken our understanding of whimsy's contradictions and possibilities.

\section{Gifts of Whimsy}

Bishop's notion of whimsy as a 'gift' is suggestive, allowing readers to get something they were not expecting, but to receive it in gratitude. This suggests less that whimsy is of no worth, and more that poets or their readers cannot be sure of its value. Parker and Moore's poetry explores this idea through sustained attention to how we value the things we make, give, and receive. An implicit conversation between Parker's poem 'Bric-á-Brac' (Parker 1928) and Moore's 'Walking-Sticks and Paperweights and Watermarks' (1936) suggests the complex relationship between all three. Parker's 'Bric-á-Brac' details the 'Little things that no one needs-/Little things to joke about' —(Parker 2010, 
p. 102). The two stanzas recount the domestic miniatures of 'little landscapes' and 'little morals, woven out', and the 'little brigs of whittled oak/Bottled painfully in glass'. In the final stanza, we learn the combination of littleness and profusion is not accidental:

Lonely folk have lines of days

Long and faltering and thin;

Therefore-little wax bouquets,

Prayers cut upon a pin,

Little maps of pinkish lands,

Little charts of curly seas,

Little plats of linen strands,

Little verses, such as these. (Parker 2010, p. 102)

The repetition of little, like the obsessive return to the word 'whimsical' in Parker's reviews, suggests a quality that is difficult to quantify, so easier to repeat. The final line brings us up short, but enacts a Janus-turn too. The poem moves from a sniggering, if melancholy, inventory of domestic craft to elegiac self-diagnosis. The final deictic 'such as these' does painful work: by making an example of itself, the poem is both allowed to be entirely generic, and-exceptionally-to sigh for being so. It is built from layers of the time-killing littleness it observes. If Parker's reviews ensured she was never accused of whimsy by accusing others first, this poem refuses the insult by being the first to make it.

We seem to be in the world of what Derrida has called the 'frivolous', where the 'utility' of what is being described bears only on 'objects of little consideration or worth' (Derrida 1987, p. 118). Yet the poem is too knowing to cast itself as unnecessary, and its claim to be no more substantial than what it describes is disingenuous. By the poem's conclusion, it is no longer funny enough for a reader to 'joke about', but more complex than the earlier pathos for the 'lonely folk'. The poem reveals the rich and complex literary affects prompted by its 'bric-á-brac', and uncovers, underneath the unwanted objects, the profound feelings of the makers. While an art work might be dismissed as whimsical, its process of 'painful' bottling may be less so. If Parker's criticism glossed whimsy as an immovable obstacle-'what can you do about it?'- - her poetry shows the affective power of what it can do. The poem's self-professed littleness matched Parker's own diminutive comments on her poetry. In a 1956 Paris Review interview, Parker declared, 'my verse is terribly dated [ ... ] I gave it up, knowing it wasn't getting any better, but nobody seemed to notice my magnificent gesture' (Capron 1956). Yet her remark is more than wry shoulder-shrugging: like the poem, it suggests a mode which downplays its significance only to draw attention to itself.

Moore's notoriously opaque poem 'Walking-Sticks and Paperweights and Watermarks' (1936), which Luke Carson and Heather Cass White have noted remains 'mostly invisible to Moore scholarship' (Carson and White 2010, p. 341), also shows the complex burden of apparently insubstantial and whimsical gifts. If Parker's poem offers itself as a thing which no-one needs, Moore's poem was similarly discarded. Moore herself partially revised it before omitting it entirely from subsequent Complete Poems (1967). It sums up its own value with ambivalence: in the course of the poem, Moore's speaker describes a copy of her recent poetry collection The Pangolin and Other Verse (1936) as merely' an alphabet/of words and animals', and doubts the 'high-/way's wide giant trivia' (Moore 2017, p. 126). Like Parker's 'magnificent gesture' of renunciation, the scale of dismissal ('giant trivia') upsets its intent. The poem is built around a series of objects which make hovering analogies with the work itself, mostly private gifts which circulated among Moore and her close friends. The references for many of its quotations often rely on an intimate knowledge of a particular context, the tenor of its words on understanding what Empson called a 'compacted doctrine' (Empson 1948, p. 230). While Parker's 'Bric-á-Brac' was full of objects so everyday they resisted further comment, Moore's poem is built with objects so particular in meaning their worth cannot be understood. 
The objects in the poem are often made frail by questions about their durability, purpose and utility, building a 'fabric of inconsistency' which is 'moth eaten by self-substractives' (p. 124). The ornate, private, and gnomic qualities of the poem re-animate the 'thin' lines of Parker's domestic crafts. Its world is whimsical because while the eye can admire the beauty of the objects, it cannot explain the purpose of their arrangement, or their significance to the figures bestowing them. The poem is peppered with incentives to peel back its obscure layers, quoting the Dominican friar Giordano Bruno who held that 'difficulty is ordained to check/poltroons', (p. 124), but the reader is found wanting courage. Like the 'linen strands' knitted together in Parker's poem, the gift of the poem itself is one readers often do not know where to put or what to say on receiving. The presents given by whimsy are often handed out shyly, obscurely, and may not reach the reader at all. In this context, the poem's final stanza is telling, rewriting the festive carol of cumulative gift-giving:

"On the first day of Christmas

My true love he sent unto me, part of a

Bough of a juniper-tree",

Javelin-ed consecutively. (Moore 2017, p. 128)

As Carson and Cass White suggest, this allusion combines the Christian story of redemption with the wish-fulfilment of a fairy tale, hoping to 'find a third term' that moves between doctrine and fancy (p. 359). In the final difficulty of the poem, we find a need for a word that can move between the miraculous and imaginary. The consecutive 'javelining' of the allusion animates a peculiarity of the carol, too: each day brings gifts surplus to requirements. If the carol's gifts of turtle doves and French hens are always symbolic, their cumulative effect can be preposterous. As we move closer to epiphany, the number of gifts multiplies, but the arrangement between them becomes ever-more perplexing. The two poems help map the journey between a work which declares that no-one needs it, and a work which needs to be known, but which no-one knows they need. Both might be taken for a kind of whimsy, and were partially dismissed by the writers themselves. Yet both poems also help us understand the surprisingly rich qualities of whimsy, drawing attention to its power, puzzle and pathos. They also show its breadth: we are led from the whimsy of the insubstantial in Parker to the whimsy of the inscrutable in Moore. If its gifts come unbidden, or are given ambivalently, can they still be cherished?

\section{The Whimsical Poet}

Moore and Parker suggest further ways to appreciate these gifts by attending to the uneven reception of whimsical writers. We are often encouraged to rethink the worth of minor poets in Moore's and Parker's work, to see the gaps and contingencies between their writing and their reputation. A series of Parker's epigraphs for writers mock-memorialises the unlettered and ungarlanded:

His little trills and chirpings were his best

No music like the nightingale's was born

Within his throat; but he, too, laid his breast

Upon a thorn.

('The Minor Poet, from Tombstones in Starlight', Parker 2010, p. 163)

The quatrain hovers between wry rib-tickling and gentle deflation. The accusation of being 'minor' or 'little' is qualified by being a subject worthy of elegy, though the poem's preference for his 'little trills' might suggest, similarly, that Parker's poem is a minor one. Its final line cuts itself off in mid-song, flattened into a stubby elegy: this act of affinity — a minor epitaph for a minor poet—complicates his status as a subject of ridicule. The task of authorship is no easier for the writer of 'trills' and 'chirpings'. These poems are often in dialogue with her own reputation: in 1927, Parker's fellow Vanity Fair 
columnist E.E. Cummings satirized her literary pretensions with a wry tribute to the fictional 'poetess' named Helen Whiffletree, murdered in Paris. He gathers together enough topical allusions to make Parker a possible object of his satire. The mock-tribute celebrates a poetry where 'naivetë is carried to a pitch of unheard-of poignancy', and summons a comic portrait of the Algonquin set, as Helen arrives 'penniless but exultant, in Greenwich Village' to find a 'coterie of struggling artists and models, many of whom lent her money in small quantities as a tribute to the surge of odes, triolets, roundels, roundeaux, chants royals [... ] which poured from her teeming brain almost ceaselessly at this fecund time' (Cummings 2017, p. 123). As the 'teeming' suggests, this is also the familiar model of the women poet as whimsical. The verse forms he lists are often seen as light, trivial, or absurdly over-complicated.

Parker responds with a series of parodies of modernist literary culture, which always work to lower the stakes. In her essays and opinion pieces, she summons a literary culture where 'to have written anything, whether it be a Ulysses or whether it be a report of who sat next to whom at the P.E.N. Club dinner, is to be a writer' (p. 64). In a work subtitled 'Showing that Anyone Can Write Modernist Verse', Parker offers a wry sequence of four poetic pastiches: Eliot's 'newspaper from vacant lots' from 'Preludes' (Eliot 1999, p. 9) become a 'litter of newspapers/Piled in smothering profusion' (Parker 2010, p. 227). Yet the newspapers are more beguiling than they should be, and the modernist manqué cannot quite leave them alone. Their 'supplements' are 'sprawling shamelessly open' presenting their 'lurid contents' to editorials 'crumpled in a frenzy of ennui'. The 'endless' and 'beginningless' heaps of newspapers pile ever higher, suggesting the gap between 'news' and 'news that stays news' is not so wide. If anyone can write modernist verse, anyone, too, might find themselves writing whimsy.

While Moore's own poetic portraits are necessarily more abstruse, there is a telling evocation of whimsical authorship in her 1916 poem "'He Wrote the History Book", It Said'. The poem, first published in the Egoist in 1916, recounts a conversation Moore had with a young boy named John, son of the historian Dr. C.M. Andrews, and takes his words as its title. Ostensibly, the poem mocks authority and individual claims to being definitive:

THERE! You shed a ray

Of whimsicality on a mask of profundity so

Terrific that I have been dumbfounded by

It oftener than I care to say. The book? Titles are chaff. (Moore 2017, p. 30)

Its central metaphorical tenet is to make whimsy a 'ray' and profundity 'a mask'. Whimsy is that unexpected beam of light which illuminates and explains, and profundity the forbidding disguise that hides a subject from us. The dismissive 'titles are chaff' might also implicate the title of this poem as mere dictation, or whimsy. Yet the poem's final sentence-'Thank you for showing me/Your father's autograph'-attempts another kind of playful inversion, laying doubt on the whole literary discourse of the poem by signing off with a low-key envoi. Moore makes still greater claims for what a whim might be, something not with hidden depths but hidden under depths. Both Parker and Moore, by considering in their own work how writers are categorised, and the role of literary and social contexts in defining it, show that mood and mode cannot be separated from social categories. The minor poet might still have a life worth recording, and the authoritative male historian might skate closer to frivolity than we expect. In both cases, Moore and Parker respond to potential attacks on their work by finding whimsy in unusual places, then detailing the ways we might value it.

As Moore's poem 'Novices' notes, the artist is 'the only seller who buys, and holds on to the money' (Moore 2017, 'Novices', p. 61). Moore's reductio-ad-absurdum of her collected works, vanishing stanzas when republishing her work or omitting poems altogether, offered a poetic economy that made new economic product from absence and destruction. In accepting the 1955 commission from the Ford Motor Company, and republishing their correspondence first in The New Yorker and then The Marianne Moore Reader, Moore aligned modern American poetry squarely with capitalism. As Irene 
Ramalho Santos notes, the decision was 'not in opposition to but taking into account the rhythms and achievements of material culture' (Santos 2003, p. 265). Perhaps, in an age which suggested that the poem should 'work', like a machine or a pudding, this was no great mismatch (Wimsatt 1954, p. 4). Yet the project, like the car itself, could hardly be considered a success, even if the resulting correspondence makes wonderful reading: Moore begins by refusing to take a fee for her pains as she wishes to carry out the commission with 'unencumbered fancy' (Moore 1958, unpaginated). Moore's increasingly absurd suggested names for the Ford-Mongoose Civique, Utopian Turtletop, Dearborn Diamonte-were all politely rejected for the name of Ford's son, Edsel. Yet the final tagline for the car that, after all, Marianne Moore did not name is revealing: 'The EDSEL acts the way it looks, but it doesn't cost that much' (Neil 2016). By this point, the advertising campaign had nothing whatsoever to do with Moore, who had magisterially withdrawn from proceedings, but the tagline invites application to her own work and the mood that propels so much of it forwards. Whimsy neither acts the way it looks, not costs as little as it seems. Like the animals celebrated in Moore's poem 'Diligence is to Magic as Progress is to Flight', that have 'outstripped man's whim to suppose/them ephemera' (Moore 2017, p. 18), the work of Parker and Moore shows us how a diminutive mode can be capable of more than we can understand or express.

\section{Conclusions}

Whimsy is a literary-critical term that is most often an insult, negation, or act of dismissal, and an aesthetic category which has received little sustained attention. It has been applied particularly to poetry, and often to female authors. Its tendency to invoke a range of moods and modes makes it a challenge to understand its characteristics or affects. It has been the contention of this article that the work of women poets most often accused of being whimsical gives us a helpful starting point for considering the cultural, aesthetic, and political meanings of the term. By attending to the poetry of Marianne Moore and Dorothy Parker, I have suggested that whimsy is a mode which can often challenge its readers to question the value and process of meaning-making. Although it is a socially-constructed category, close attention to the work of 'whimsical' poets nevertheless opens the way to significant aesthetic questions of scale, affect, and value. Moore's cat poem 'Peter' (1920) encourages us to 'fly over the fence' and 'go in the wrong way' (Moore 2017); whimsy might be the way poets makes right from our wrongs, and attending carefully to its pawprint might show us how many trails it leaves in modernist women's poetry and its reception. The history of poetry counts whimsy as a poetic dismissal, but Moore and Parker's work uses it to identify limitations in our own readings, rather than the poems we read. As Moore put it in her commission from the Lead Pencil Manufactures Association: 'Velvet mat/is my cat [ ... ] Our best pencils/write like that' (Moore 2017, p. 420). Careful attention to the cultural politics and aesthetic possibilities of diminutive modes not only allows us to understand why and how poets are said to 'write like that', but rethink how dangerous 'that' might be. Judging by Moore and Parker, those most at risk of whimsical accusations proved the most dexterous in reframing them as possibilities.

Funding: This research received no external funding.

Conflicts of Interest: The author declares no conflict of interest.

\section{References}

Adams, Franklin Pierce. 1935. The Diary of Our Own Samuel Pepys. London: Simon \& Schuster, vol. 2.

Aldrich, Thomas Bailey. 1892. Emily Dickinson. Atlantic Monthly 69: 283.

Bishop, Elizabeth. 1994. Efforts of Affection: A Memoir of Marianne More. In Collected Prose. London: Chatto \& Windus.

Bromwich, David. 1982. 'Marianne Moore's Poems'. Poetry 139: 340-52.

Capron, Marion. 1956. Dorothy Parker the Art of Fiction No. 13. Available online: https://www.theparisreview. org/interviews/4933/dorothy-parker-the-art-of-fiction-no-13-dorothy-parker (accessed on 20 February 2020). 
Carson, Luke, and Heather Cass White. 2010. Difficult Ground: Poetic Renunciation in Marianne Moore's “Walking-Sticks and Paperweights and Watermarks". Twentieth-Century Literature 56: 340-70. [CrossRef]

Cavendish, Margaret. 1668. The Female Academy. In Plays, Never before Printed. London: Maxwell.

Costello, Bonnie. 1984. Marianne Moore and Elizabeth Bishop: Friendship and Influence. Twentieth Century Literature 30: 130-49. [CrossRef]

Costello, Bonnie. 2012. Tragicomic Mode in Modern American Poetry: "Awful But Cheerful". In A Companion to Poetic Genre. Edited by Erik Martiny. Hoboken: John Wiley \& Sons, pp. 630-35.

Crawford, Robert. 2004. The Modern Poet: Poetry, Academia and Knowledge Since the 1750s. Oxford: Oxford University Press.

Cummings, Edward Estlin. 2017. Helen Whiffletree, American Poetess. In Miscellany. Edited by George James Firmage. New York: Liveright Publishing.

Dennis, John. 1704. The Grounds of Criticism. London: George Strahan and Bernard Lintott.

Derrida, Jacques. 1987. The Archaeology of the Frivolous. Lincoln: University of Nebraska.

Dyer, Geoff. 2012. But Beautiful: A Book about Jazz. London: Canongate.

Eliot, T. S. 1935. 'Introduction' in Marianne Moore. In Selected Poems. London: Faber.

Eliot, T. S. 1999. The Waste Land and Other Poems. London: Faber.

Empson, William. 1948. The Complex Structure of Words. The Sewanee Review 56: 230-50.

Hazlitt, William. 1817. Review of Coleridge's Biographia Literaria. Edinburgh Review, August 28, pp. 488-515.

Howe, Susan. 1993. The Birth-Mark: Unsettling the Wilderness in American Literary History. London: Wesleyan University Press.

Johnson, Samuel. 1875. Lives of the English Poets. Oxford: Oxford World's Classics.

Kelly, Lionel. 2000. Introduction. In Poetry and the Sense of Panic: Critical Essays on Elizabeth Bishop and John Ashbery. Amsterdam: Rodopi, pp. 1-8.

Logan, William. 2004. The Mystery of Marianne Moore. The New Criterion. February. Available online: https://www.newcriterion.com/issues/2004/2/the-mystery-of-marianne-moore (accessed on 1 February 2020).

Mak, Cliff. 2016. On Falling Fastidiously: Marianne Moore's Slapstick Animals. ELH 83: 873-98. [CrossRef]

May, Will. 2019. 'Plath's Whimsy'. In Sylvia Plath in Context. Edited by Tracy Brain. Cambridge: Cambridge University Press, pp. 74-82.

Meade, Marion. 1988. Dorothy Parker: What Fresh Hell Is This? London: Heinemann.

Moore, Marianne. 1958. Letters from and to the Ford Motor Company. New York: Pierpont Morgan Library.

Moore, Marianne. 2017. New Collected Poems. Edited by Heather Cass White. London: Faber.

Neil, Dan. 2016. 50 Worst Cars of All Time. Time. Available online: https://time.com/4723114/50-worst-cars-of-alltime/ (accessed on 20 February 2020).

Ngai, Sianne. 2012. Zany, Cute, Interesting. Cambridge: Harvard University Press.

O'Connor, John J. 1988. Putting Marianne Moore in Perspective. The New York Times, March 17.

Parker, Dorothy. 1928. Reading and Writing. The New Yorker, January 7.

Parker, Dorothy. 1970. 'Far from Well' [New Yorker, October 20, 1928]. London: Viking Press, pp. 100-1.

Parker, Dorothy. 2010. Complete Poems. Edited by Marion Meade. London: Penguin.

Parker, Dorothy. 2014. Complete Broadway, 1918-1923. Edited by Kevin C. Fitzpatrick. Bloomington: iUniverse LLC. Rich, Adrienne. 1995. On Lies. Secrets, and Silence: Selected Prose 1966-1978. New York: Norton.

Richards, I. A. 1930. Practical Criticism. London: Kegan.

Santos, Irene Ramalho. 2003. Poetry in the Machine Age. In The Cambridge History of American Literature Vol. 5: Poetry and Criticism, 1900-1950. Edited by Sacvan Bercovitch. Cambridge: Cambridge University Press, pp. 180-343.

Sontag, Susan. 1966. Ionesco. In Against Interpretation and Other Essays. London: Picador.

[Unsigned Article]. 1956. Education: A Man Who Hated Whimsy. Time. Available online: http://content.time.com/ time/subscriber/article/0,33009,893397-1,00.html (accessed on 20 February 2020).

Whimsy. 2019. The Merriam-Webster.com Dictionary. Available online: https://www.merriam-webster.com/ dictinoary/whimsy (accessed on 5 December 2019). 
Wimsatt, William Kurtz. 1954. The Verbal Icon: Studies in the Meaning of Poetry. Lexington: University of Kentucky. Wollstonecraft, Mary. 2008. A Vindication of the Rights of Woman E a Vindication of the Rights of Men. Oxford: Oxford University Press. (CC BY) license (http://creativecommons.org/licenses/by/4.0/). 